\title{
Serum biochemistry profile of laying hens fed diets with fish waste oil
}

[Parâmetros bioquímicos sanguíneos de poedeiras leves alimentadas com rações contendo óleo do resíduo de pescado]

K.C.B.T.R. Brelaz ${ }^{1}$, F.G.G. Cruz ${ }^{2 *}$, J.P.F. Rufino ${ }^{1}$, R.J.M. Brasil ${ }^{1}$, A.F. Silva ${ }^{3}$, A.N.A. Santos ${ }^{3}$

\author{
${ }^{1}$ Aluno de pós-graduação - Universidade do Estado do Amazonas - Manaus, AM \\ ${ }^{2}$ Faculdade de Ciências Agrárias - Universidade Federal do Amazonas - Manaus, AM \\ ${ }^{3}$ Aluno de pós-graduação - Universidade Federal do Amazonas - Manaus, AM
}

\begin{abstract}
The present study aimed to evaluate increasing levels of fish waste oil in diets for laying hens on serum biochemistry profile. 192 Hisex White laying hens at 29 weeks of age were used, with water and food ad libitum. The experimental design was completely randomized consisting of eight treatments corresponding to the inclusion levels of fish waste oil $(0,0.5,1.0,1.5,2.0,2.5,3.0$ and $3.5 \%)$ in the diets, with four replicates of six birds each. Data collected were subjected to polynomial regression at $5 \%$ of significance. Significant differences $(\mathrm{P}<0.05)$ were observed in triglycerides, glucose, total cholesterol, and uric acid. These parameters presented a decrease when hens fed diets with higher level of fish waste oil. The results of the present study indicated that the inclusion of fish waste oil caused a significant effect in the serum biochemical profile of laying hens, especially in glucose, triglycerides, total cholesterol, and uric acid concentrations. The inclusion level of 3.5\% of fish waste oil caused larger disequilibrium in the serum biochemical profile of laying hens.
\end{abstract}

Keywords: albumin, alternative food, by-product, cholesterol, triglycerides

\section{RESUMO}

O presente estudo objetivou avaliar os níveis crescentes de óleo de resíduo de pescado em dietas para poedeiras leves sobre o perfil bioquímico sérico. Foram utilizadas poedeiras Hisex White com 29 semanas, com água e ração ad libitum. $O$ delineamento experimental foi inteiramente ao acaso, consistindo de oito tratamentos correspondentes aos níveis de inclusão de óleo de resíduo de pescado $(0 ; 0,5 ; 1,0 ; 1,5 ; 2,0$; 2,5; 3,0 e 3,5\%) nas dietas, com quatro repetições de seis aves cada. Os dados coletados foram submetidos à regressão polinomial a $5 \%$ de significância. Diferenças significativas $(P<0,05)$ foram observadas nas concentrações de triglicerídeos, glicose, colesterol total e ácido úrico. Esses parâmetros apresentaram uma diminuição quando as aves se alimentaram com rações contendo maior nível de óleo do resíduo de pescado. Os resultados do presente estudo indicaram que a inclusão de óleo do resíduo de pescado acarretou um efeito significativo no perfil bioquímico sérico de poedeiras, principalmente nas concentrações de glicose, triglicerídeos, colesterol total e ácido úrico. O nível de inclusão de 3,5\% do óleo do resíduo de pescado acarretou maior desequilíbrio no perfil bioquímico sérico das poedeiras.

Palavras-chave: albumina, alimento alternativo, colesterol, subproduto, triglicerídeos

\section{INTRODUCTION}

Feedstuffs of animal origin are an important source of nutrients to animal diets. Fish byproducts represents one of the most important feedstuffs of animal origin used, represent up to $60 \%$ of the total that is produced and/or captured per year by the aquaculture (Arvanitoyannis and Kassaveti, 2008; Silva et al., 2017). The use of fish waste as alternative food in poultry diets are

Recebido em 30 de outubro de 2019

Aceito em 25 de maio de 2020

*Autor para correspondência (corresponding author)

E-mail: frankgcruz@gmail.com 
not an innovation in the poultry industry, mainly due to these offer advantages to regions that present barriers to grain logistics and high-cost feedstuffs (Jafari et al., 2006; Cruz et al. 2016).

Fish oils are rich sources of omega- 3 fatty acids and poor sources of omega- 6 , and the contents of linoleic acid are also low (Mariod et al., 2015). Currently, omega-3 fatty acid-rich fish oil has been widely used in food, pharmaceutical and health products industry, especially on the European and American market. At the same time, scientists in the animal nutrition field hoped to diversify the source of omega-3 fatty acid alternative to fish products. Their investigations also indicated that inclusion of various fish oil in hen diets result in significant increase in yolk omega-3 fatty acids (Dong et al., 2018).

The inclusion of various fish oil in hen diets may result in a significant increase on fatty acids content in yolk, producing the named "enriched eggs" (Gonzalez-Esquerra and Leeson, 2000; Cherian et al., 2002, 2007), a popular trend in the worldwide market (Dong et al., 2018). The use of fish oil in the poultry diets also reduce the synthesis of fatty acids, making the bird accumulate more energy for meat or egg production, and increasing the level of long-chain n-3 fatty acids in these products (Chanmugam et al., 1992; Pinchasov and Nir, 1992). However, this oil may also provide some organoleptic problems that adversely affect the acceptability of poultry products due to the peculiar odor and flavor of fish that are transferred (Edwards and May, 1965; Miller and Robisch, 1969; Pucci et al., 2003).

Blood biochemistry is a very important tool to evaluate the physiological condition of birds, especially to verify how different situations may affect the bird, for example the environmental conditions, or effect of food in birds' metabolism (Artacho et al., 2007; Schmidt et al., 2007; Huang et al., 2018). In this sense, blood analyses are widely used to monitor general health with physiological processes in birds as part of efforts to increase productive attributes (Cooper, 1998; Naidoo et al., 2008; Han et al., 2011; Ortizo et al., 2014). While interpreting data pertaining to blood analyses for animals, it is possible to analyze how the nutrition can affect the organism and transfer organoleptic characteristics to their products (meat, eggs, among others) (Howlet et al., 1998; Bailey et al., 1999). Thus, the objective of this study was to evaluate increasing levels of fish waste oil in diets for laying hens on serum biochemistry profile.

\section{MATERIAL AND METHODS}

The experimental procedures were developed in the facilities of the Poultry Sector, College of Agrarian Sciences, Federal University of Amazonas, Manaus, Amazonas State, Brazil. All procedures were approved by the Ethics Committee in Use of Animals (protocol $n$. 012/2017) of Federal University of Amazonas. The experimental period lasted 105 days, being divided into five 21 day periods. The birds were subjected to a previous adaptation period of seven days to the diets and facilities. The aviary $(17.0 \mathrm{x}$ $3.5 \mathrm{~m}$ ) used had galvanized wire cages, trough feeders, and nipple drinkers.

192 Hisex White laying hens with 29 weeks-ofage were used. Birds were weighed in the beginning of the experimental period to standardize the plots, presenting an average weight of $1.45 \pm 0.0025 \mathrm{~kg}$. The temperature and relative humidity were recorded two times a day (9:00 a.m. and 3:00 p.m.) using a digital termhygrometer positioned above the birds' cage, and presenting averages of $30.38^{\circ} \mathrm{C}$ and $67.13 \%$, respectively. The experimental design was completely randomized constituted by eight treatments corresponding to the inclusion levels of fish waste oil $(0,0.5,1.0,1.5,2.0,2.5,3.0$, and $3.5 \%$ ) in the diets, with four replicates of six birds each. Throughout the experimental period, 16 hours of the light/day (12 natural hours +4 artificial hours) were provided to the birds.

The fish waste oil was from fish processing plant of RIOMAR@, Itacoatiara town, Amazonas State, Brazil. This product was obtained from pressing of freshwater fish waste (head, bony structure, fins, tissue, and visceral residue) in the industrial level. The composition and fatty acids profile of fish waste oil was determined in the CBO Laboratories $^{\oplus}$ (Campinas, São Paulo, Brazil), and its results are present in Table 1. The experimental diets were formulated according to the nutritional requirements of laying hens according to Rostagno et al. (2017), using the composition obtained for fish waste oil (Table 2). 
Table 1. Composition of fish waste oil

\begin{tabular}{|c|c|}
\hline Components & Composition \\
\hline Palmitic acid (C16:0), \% & 29.01 \\
\hline Stearic acid (C18:0), \% & 9.62 \\
\hline Oleic acid $(\mathrm{C} 18: \ln 9 \mathrm{c}), \%$ & 18.48 \\
\hline Linoleic acid (C18:2n6c) & 4.39 \\
\hline Alpha Linolenic acid LNA (C18:3n3) & 4.51 \\
\hline Arachidonic acid AA (C20:4n6) & 3.09 \\
\hline Eicosapentaenoic acid 5,8,11,14,17- EPA (C20:5n3) & 3.26 \\
\hline Docosahexaenoic acid DHA(C22:6n3) & 4.20 \\
\hline Omega $3, \%$ & 12.79 \\
\hline Omega $6, \%$ & 8.57 \\
\hline Omega $9, \%$ & 20.37 \\
\hline Monounsaturated fat, $\%$ & 28.92 \\
\hline Polyunsaturated fat, $\%$ & 21.91 \\
\hline Unsaturated fat, $\%$ & 50.83 \\
\hline Saturated fat, $\%$ & 48.23 \\
\hline Humidity and volatiles, $\%$ & 0.19 \\
\hline Ethereal extract, \% & 99.06 \\
\hline Acidity, $\%$ & 13.38 \\
\hline Peroxide index, meq $/ \mathrm{kg}$ & 4.36 \\
\hline Iodine index, meq $/ \mathrm{kg}$ & 85.37 \\
\hline
\end{tabular}

Table 2. Diet compositions containing fish waste oil

\begin{tabular}{|c|c|c|c|c|c|c|c|c|}
\hline \multirow{2}{*}{ Ingredients } & \multicolumn{8}{|c|}{ Fish waste oil (\%) } \\
\hline & 0 & 0.5 & 1.0 & 1.5 & 2.0 & 2.5 & 3.0 & 3.5 \\
\hline Corn $(7.88 \%)$ & 65.0529 & 63.7356 & 62.5469 & 60.5696 & 58.2469 & 55.2459 & 54.3412 & 52.1422 \\
\hline Soybean meal $(46 \%)$ & 23.2198 & 23.2741 & 23.3068 & 23.1381 & 22.6938 & 22.5048 & 22.6845 & 22.0501 \\
\hline Wheat meal & 0.0000 & 0.5000 & 1.0000 & 2.5000 & 5.0000 & 7.5000 & 7.5000 & 10.0000 \\
\hline Fish waste oil & 0.0000 & 0.5000 & 1.0000 & 1.5000 & 2.0000 & 2.5000 & 3.0000 & 3.5000 \\
\hline Limestone & 8.8070 & 9.0744 & 9.2352 & 9.3998 & 9.2005 & 9.4005 & 9.6488 & 9.5122 \\
\hline Dicalcium phosphate & 1.9812 & 1.9760 & 1.9706 & 1.9520 & 1.9195 & 1.9095 & 1.8877 & 1.8568 \\
\hline Vit.min.supplement ${ }^{1}$ & $0.5000^{1}$ & $0.5000^{1}$ & $0.5000^{1}$ & $0.5000^{1}$ & $0.5000^{1}$ & $0.5000^{1}$ & $0.5000^{1}$ & $0.5000^{1}$ \\
\hline Salt & 0.3500 & 0.3500 & 0.3500 & 0.3500 & 0.3500 & 0.3500 & 0.3500 & 0.3500 \\
\hline DL-methionine (99\%) & 0.0891 & 0.0899 & 0.0905 & 0.0905 & 0.0893 & 0.0893 & 0.0878 & 0.0887 \\
\hline Total & 100.00 & 100.00 & 100.00 & 100.00 & 100.00 & 100.00 & 100.00 & 100.00 \\
\hline Nutrient & \multicolumn{8}{|c|}{ Nutritional levels } \\
\hline M.E., kcal. $\mathrm{kg}^{-1}$ & $2,727.3$ & $2,736.7$ & $2,750.5$ & $2,750.5$ & $2,750.5$ & $2,745.7$ & $2,750.5$ & $2,750.5$ \\
\hline Crude protein, $\%$ & 16.000 & 16.000 & 16.000 & 16.000 & 16.000 & 16.000 & 16.000 & 16.000 \\
\hline Calcium, $\%$ & 3.900 & 3.900 & 3.900 & 3.900 & 3.900 & 3.900 & 3.900 & 3.900 \\
\hline Available phosphorus, $\%$ & 0.450 & 0.450 & 0.450 & 0.450 & 0.450 & 0.450 & 0.450 & 0.450 \\
\hline Methionine, $\%$ & 0.344 & 0.344 & 0.344 & 0.344 & 0.342 & 0.340 & 0.340 & 0.339 \\
\hline Met. +cystine, $\%$ & 0.600 & 0.600 & 0.600 & 0.600 & 0.600 & 0.600 & 0.600 & 0.600 \\
\hline Sodium, $\%$ & 0.156 & 0.156 & 0.156 & 0.156 & 0.156 & 0.156 & 0.155 & 0.155 \\
\hline
\end{tabular}

${ }^{1 \mathrm{~g}}$ uaranteed levels per kilogram of the product: Vitamin A 2,000,000 IU, Vitamin D3 400,000 IU, Vitamin E 2,400mg, Vitamin K3 400mg, Vitamin B1 100mg, Vitamin B2 760mg, Vitamin B6 100mg, Vitamin B12 2,400mcg, Niacin $5,000 \mathrm{mg}$, Calcium Pantothenate 2,000mg, Folic acid 50mg, Coccidiostat 12,000mg, Choline 50,000mg, Copper 1,200mg, Iron 6,000mg, Manganese 14,000mg, Zinc 10,000mg, Iodine 100mg. Selenium 40mg. Vehicle q.s.p. 1,000g.

On the last day of the 21 day period, blood samples for biochemical analyses were collected from v. Subcutanea ulnaris of randomly selected four birds of each treatment. The collected blood was placed into heparin-treated tubes and serum separator tubes, and serum was obtained from the clotted blood in the serum separator tube after centrifugation at $1,500 \times \mathrm{g}$ for $5 \mathrm{~min}$. The blood serum biochemical parameters analyzed were total proteins, albumin, globulins, uric acid, albumin /globulins (A/G ratio),glucose, triglycerides, and total cholesterol. These parameters were determined using an electronic spectrophotometer (ThermoMultiskanGo®). 
All data collected in this study were analyzed using the gLM procedure of SAS (Statistical Analysis System, v. 9.2) and estimates of treatments were subjected to ANOVA and subsequent polynomial regression analysis. Results were considered significant at $\mathrm{P} \leq 0.05$.

\section{RESULTS AND DISCUSSION}

The results regarding of serum biochemistry profile of laying hens fed diets with fish waste oil are present in Table 3. Significant differences $(\mathrm{P}<0.05)$ were observed in triglycerides, glucose, total cholesterol, and uric acid.
A quadratic effect $(\mathrm{P}<0.05)$ was observed on triglyceride concentration $\left(\mathrm{y}=-30.184 \mathrm{x}^{2}+\right.$ $\left.156.865 x+14.55 ; R^{2}=0.70\right)$, where a significant decrease in hens' blood that fed diets with the higher levels of fish waste oil $(3.5 \%)$ was observed. Physiologically, the most relevant lipids in the organism are phospholipids, cholesterol, triglycerides, and fatty acids. Triglycerides presents three fatty acids linked to a glycerol molecule, being one of most important kinds of energy storage in the body, deposited in adipose, and muscle tissues (Lehninger et al., 2006; Sposito et al., 2007).

Table 3. Triglycerides (TRI), Total cholesterol (TCH), glucose (GLU), Total proteins (TPR), Albumin (ALB), globulins (GLO), Albumin/Globulins ratio (A/G), and Uric acid (URA) concentrations in the blood of laying hens fed diets with different levels of fish waste oil

\begin{tabular}{|c|c|c|c|c|c|c|c|c|c|c|c|}
\hline & \multicolumn{8}{|c|}{ Levels of inclusion of fish waste oil (\%) } & \multirow{2}{*}{$\begin{array}{c}\text { p- } \\
\text { value }\end{array}$} & \multirow{2}{*}{$\mathrm{R}^{2}$} & \multirow{2}{*}{$\begin{array}{c}\mathrm{CV} \\
\%\end{array}$} \\
\hline & 0.00 & 0.50 & 1.00 & 1.50 & 2.00 & 2.50 & 3.00 & 3.50 & & & \\
\hline TRI,mg.dl ${ }^{-1}$ & 208.32 & 205.29 & 209.36 & 207.31 & 215.15 & 214.63 & 199.84 & 36.17 & 0.01 & $0.70^{\mathrm{Q}}$ & 14.60 \\
\hline TCH,mg.dl ${ }^{-1}$ & 126.12 & 158.52 & 159.36 & 176.52 & 168.60 & 177.56 & 165.42 & 226.18 & 0.01 & $0.67^{\mathrm{Q}}$ & 5.99 \\
\hline GLU,mg.dl ${ }^{-1}$ & 126.73 & 164.36 & 166.51 & 157.29 & 161.03 & 160.29 & 172.67 & 175.92 & 0.01 & $0.57^{Q}$ & 7.54 \\
\hline TPR,g.dl ${ }^{-1}$ & 2.43 & 2.58 & 2.53 & 2.59 & 2.58 & 2.58 & 2.51 & 2.55 & 0.07 & ns & 2.80 \\
\hline ALB,g. $\mathrm{dl}^{-1}$ & 1.22 & 1.26 & 1.38 & 1.33 & 1.28 & 1.36 & 1.28 & 1.22 & 0.36 & ns & 8.90 \\
\hline GLO,g.dl ${ }^{-1}$ & 1.22 & 1.32 & 1.15 & 1.27 & 1.30 & 1.22 & 1.23 & 1.33 & 0.61 & ns & 11.38 \\
\hline $\mathrm{A} / \mathrm{G}$ & 0.99 & 0.96 & 1.20 & 1.08 & 0.99 & 1.15 & 1.06 & 0.92 & 0.51 & ns & 19.45 \\
\hline URA,mg. $\mathrm{dl}^{-1}$ & 2.31 & 2.01 & 2.65 & 2.38 & 3.05 & 2.31 & 2.26 & 4.99 & 0.01 & $0.52^{\mathrm{Q}}$ & 20.77 \\
\hline
\end{tabular}

$\mathrm{CV}$ - Coefficient of Variation. Q - quadratic effect $(\mathrm{P}<0.05)$. ns - non-significant $(\mathrm{P}>0.05)$.

Triglycerides are synthesized in the intestinal mucosa and liver from the components of digestion and absorption of fatty acid. Thus, their concentrations may vary depending on factors such as diet, sex and hormone concentrations (Rezende, 2017). It is important to mention that the main source of serum lipids is the dietary lipids absorbed by the intestinal mucosa. The amount and kind of food, fat profile present in the food, among other factors, directly influence the lipid concentrations in the blood (Silva et al., 2012).

Total cholesterol concentrations presented a quadratic effect $(\mathrm{P}<0.05 ; \mathrm{y}=1.2781 \mathrm{x} 2+14.136 \mathrm{x}$ $\left.+139.46 ; R^{2}=0.67\right)$, where laying hens fed diets with $3.5 \%$ of fish waste oil presented higher total cholesterol concentration than other treatments. Cholesterol is the most common lipid in body tissues and acts as a precursor in the synthesis of steroid hormones, bile salts, and vitamin D. Cholesterol circulates along the blood in free and esterified form, being synthesized mainly in the liver and transported to all cells in the body (Attie, 2007). Furthermore, the cholesterol acts as a constituent of cell membranes, being directly related to their fluidity, and activation of their enzymes (Duncan, 2000, Sposito et al., 2007).

The cholesterol values in the present study ranged from 126 to $226.18 \mathrm{mg}^{-\mathrm{dl}^{-1}}$, being in accordance with average values reported in the literature to usual cholesterol levels in chickens can range from 100 to $250 \mathrm{mg}^{-\mathrm{dl}^{-1}}$ (Swenson and O'Reece, 1996; Lumeij, 2008). In some situations, elevation of serum cholesterol may not be related to pathological changes (Alonso-Alvarez, 2005).

On the other hand, a previous study developed by Mendonça Jr. et al. (2000) evaluated the effect of the inclusion of fish oil in the diet on serum lipid levels in laying hens. The authors reported that triglycerides and total cholesterol values no presented difference between the treatments (six levels of fish oil). In other studies using flaxseed oil, sunflower oil and seaweed, products rich in omega 3 and 6 , no significant differences were observed in the triglycerides and total cholesterol concentrations in the blood of birds fed these diets 
(Ahmad et al., 2013; Neijat et al., 2016; Oliveira, 2018).

The glucose concentration results were significantly larger $\left(\mathrm{y}=-2.7719 \mathrm{x}^{2}+8.534 \mathrm{x}+\right.$ 146.29; $\left.\mathrm{R}^{2}=0.57\right)$ in laying hens fed diets containing fish waste oil than the control diet. The glucose values in this study presented average results between 126.73 and $175.92 \mathrm{mg} . \mathrm{dl}^{-1}$. These values may be associated with the 12-hour fast that the birds were submitted for blood collection. It is important to mention that serum biochemical profile may be influenced by nutritional status, sex, age, habitat, season, reproductive status, breeding, or environmental stress. In this sense, hypoglycemia may be observed when glucose levels are below 200mg.dl ${ }^{-1}$, and may be associated with prolonged fasting, severe liver disease, septicemia or endocrine disorders.

However, the delay in the separation of serum or plasma from cells does not significantly decrease glucose concentration as in mammals, once the bird erythrocytes use fatty acids and non-glucose for their metabolism (Amand, 1986; Campbell, 2004; Campbell and Ellis, 2007). Previous studies presented that the regulation of poultry glucose metabolism is similar to mammals, being influenced by insulin and glucagon concentrations, where a chicken may be present a glucose concentration between 130 and $270 \mathrm{mg}^{-d^{-}}$ ${ }^{1}$ (Swenson and O'Reece, 1996). Some authors also reported that in healthy birds glucose levels may vary from 200 to $500 \mathrm{mg}^{-\mathrm{dl}^{-1}}$ (Schmidt et al., 2007; Lumeij, 2008).

Serum concentrations of total protein, albumin, globulin and albumin-globulin ratio were not affected $(\mathrm{P}>0.05)$ by the inclusion of fish waste oil in the diets, presenting a similar behavior between the treatments evaluated. In this sense, it was observed that crude protein levels of the diets were sufficient to supply the maintenance and production requirements of the birds. According to Capitelli and Crosta (2013) this parameter may vary from 1 to $10 \mathrm{~g} \cdot \mathrm{dl}^{-1}$, where the main factors that affect these concentrations in birds are age, seasonality, management conditions and disease (Lumeij, 2008). The majority of proteins present in plasma are synthesized by the liver and act to maintaining the blood volume through the colloidal osmotic effect, participating in the maintenance of blood ph, transporting of hormones and drugs, participating in cell coagulation, and catalyzing (enzymes) and regulating (hormones) the biological processes. These are indispensable in inflammatory and immune reactions, and in the processes of tissue regeneration (Melillo, 2013).

The uric acid concentrations presented a quadratic effect $\left(\mathrm{y}=0.3176 \mathrm{x} 2-1.3436 \mathrm{x}+4.4817 \mathrm{R}^{2}=\right.$ 0.60 ), where birds fed diets with the higher level of fish waste oil $(3.5 \%)$ presented the higher concentration of uric acid. Previous studies pointed that normal uric acid levels for laying hens may range from 2 to $7 \mathrm{mg}$. dl ${ }^{-1}$. Increases in these plasma levels are usually seen when the kidneys work above $30 \%$ of their normal capacity (Schmidt et al., 2007; Lumeij, 2008; Capitelli and Crosta, 2013).

Normally, birds excrete small volumes of nitrogen through uric acid as the main product of nitrogen metabolism, constituting $60-80 \%$ of $\mathrm{N}$ excreted in the urine (Thrall et al., 2004; González and Scheffer, 2003). Uric acid is synthesized in the liver and kidneys, being excreted from tubular secretion, regardless of tubular water reabsorption. Thus, impaired in renal function may increase to the concentration of uric acid in the blood of the birds. Hyperproteic diets may also cause this increase, or a massive tissue necrosis or malnutrition (causing acceleration in protein catabolism). Dietary restriction situations that cause a mobilization of protein reserves may also be related to increase of uric acid concentration in the blood (Rajman et al., 2006).

\section{CONCLUSIONS}

The results of the present study indicated that the inclusion of fish waste oil caused a significant effect in the serum biochemical profile of laying hens, especially in glucose, triglycerides, total cholesterol, and uric acid concentrations. The inclusion level of $3.5 \%$ of fish waste oil caused larger disequilibrium in the serum biochemical profile of laying hens. 


\section{REFERENCES}

AHMAD, S.; AHSAN-UL-HAQ.; YOUSAF. M. et al. Effect of feeding whole linseed as a source of polyunsaturated fatty acids on performance and egg characteristics of laying hens kept at high ambient temperature. Rev. Bras. Cienc. Avic., v.15, p.21-26, 2013.

ALONSO-ALVAREZ, C. Age-dependent changes in plasma biochemistry of yellow-legged 314gulls (Larus cachinnans). Comp. Biochem. Physiol. A. Mol. Integr. Physiol., v.140, p.512518, 2005.

AMAND, W.B. Avian clinical hematology and blood chemistry. In: FOWLER, M.E. (Ed.). Zoo and wild animal medicine. Philadelphia: W.B. Saunders, 1986. p.264-276.

ARTACHO, P.; SOTO-GAMBOA, M.; VERDUGO, C. et al. Using haematological parameters to infer health and nutritional status of an endangered black-necked swan population. Comp. Biochem. Physiol. A Mol. Integr. Physiol., v.147, p.1060-1066, 2007.

ARVANITOYANNIS, I.S.; KASSAVETI, A. Fish industry waste: treatments, environmental impacts, current and potential uses. Int. J. Food Sci. Tech., v.43, p.726-745, 2008.

ATTIE, A.D. ABCA: at the nexus of cholesterol, HDL and atherosclerosis. Trends Biochem. Sci., v.32, p.172-179, 2007.

BAILEY, T.A.; WERNERY, U.; HOWLETT, J. et al. Age-related plasma chemistry changes in houbara and kori bustards in the United Arab Emirates. J. Wildl. Dis., v.35, p.31-37, 1999.

CAMPBELL, T.W. Clinical chemistry of birds. In: THRALL, M.A. (Ed.). Veterinary hematology and clinical chemistry. Philadelphia: Lippincott, Williams \& Wilkins, 2004. p.479-492.

CAMPBELL, T.W.; ELLIS, C.K. Avian and exotic animal hematology and cytology. Ames: Blackwell Publishing Professional, 2007. 2049p.

CAPITELLI, R.; CROSTA, L. Overview of psittacine blood analysis and comparative retrospective study of clinical diagnosis, hematology and blood chemistry in selected psittacine species. Vet. Clin. N. Am. Exot. Anim. Pract., v.16, p.71-120, 2013.
CHANMUGAM, P.; BOUDREAU, M.; BOUTTE, T. et al. Incorporation of different types of n-3 fatty acids into tissue lipids of poultry. Poult. Sci., v.71, p.516-521, 1992.

CHERIAN, G.; TRABER, M.G.; GOEGER, M.P.; LEONARD, S.W. Conjugated linoleic acid and fish oil in laying hen diets: effects on egg fatty acids, thiobarbituric acid reactive substances, and tocopherols during storage. Poult. Sci., v.86, p.953-958, 2007.

CHERIAN,G.; GOEGER, M.P.; AHN, D.U. Dietary conjugated linoleic acid with fish oil alters yolk n-3 and trans fatty acid content and volatile compounds in raw, cooked, and irradiated eggs. Poult. Sci., v.81, p.1571-1577, 2002.

COOPER, J.E. Minimally invasive health monitoring of wildlife. Anim. Welf., v.7, p.35-44, 1998.

CRUZ, F.G.G.; RUFINO, J.P.F.; MELO, R.D. et al. Perfil socioeconômico da avicultura no setor primário do estado do Amazonas, Brasil. Rev. Agroneg. Meio Amb., v.9, p.371-391, 2016.

DONG, X.F.; LIU, S.; TONG, J.M. Comparative effect of dietary soybean oil, fish oil, and coconut oil on performance, egg quality and some blood parameters in laying hens. Poult. Sci., v.97, p.2460-2472, 2018.

DUNCAN, J. Bioquímica clínica. In: DAVIDSON, M.; ELSE, R.; LUMSDEN, J. (Eds.). Manual de patología clínica em pequeños animales. Madrid: Harcourt, 2000.

EDWARDS Jr, H.M.; MAY, K.N. Studies with menhaden oil in practice-type broiler rations. Poult. Sci., v.44, p.685-688, 1965.

GONZÁLEZ, F.H.D.; SCHEFFER, J.F.S. Perfil sanguíneo: ferramenta de análise clínica, metabólica e nutricional. In: GONZÁLEZ, F.H.D.; CAMPOS, R. (Eds.). SIMPÓSIO DE PATOLOGIA CLÍNICA VETERINÁRIA DA REGIÃO SUL DO BRASIL, 2003, Porto Alegre. Anais... Porto Alegre: Universidade Federal do Rio Grande do Sul, 2003. p.73-89.

GONZÁLEZ-ESQUERRA, R.; LEESON, S. Effect of feeding hens regular or deodorized menhaden oil on production parameters, yolk fatty acid profile, and sensory quality of eggs. Poult. Sci., v.79, p.1597-1602, 2000. 
HAN, J.I.; JANG, H.J.; LEE, S.J. et al. Bacterial flora of the intestine in normal captive Oriental white storks. J. Vet. Clin., v.28, p.516-518, 2011.

HOWLETT, R.A.; PAROLIN, M.L.; DYCK, D.J. et al. Regulation of skeletal muscleglycogen phosphorylase and PDH at varying exercise power outputs. Am. J. Physiol., 275, p.418-425, 1998.

HUANG, S.; YANG, H.; REHMAN, M.U. et al. Acute heat stress in broiler chickens and its impact on serum biochemical and electrolyte parameters. Indian J. Anim. Res., v.52, p.683-686, 2018.

JAFARI, M.; PIRMOHAMMADI, R.; BAMPIDIS, V. The use of dried tomato pulp in diets of laying hens. Int. J. Poult. Sci., v.5, p.618$622,2006$.

LEHNINGER, A.L.; NELSON, D.L.; COX, M.M. Princípios de bioquímica. São Paulo: Sarvier, 2006. 975p.

LUMEIJ, J.T. Avian clinical biochemistry. In: KANEKO, J.J.; HARVEY, J.W.; BRUSS, M.L. (Eds.). Clinical biochemistry of domestic animals. Waltham: Academic Press, 2008. p.839-872.

MARIOD, A.A.; MUKHTAR, M.A.E.; SALIH, M.E. et al. Effect of addition of fish oil on the performance parameters of laying hens and the fatty acid composition of their egg yolk. Am. J. Nutr. Food Sci., v.1, p.38-42, 2015.

MELILLO, A. Applications of serum protein electrophoresis in exotic pet medicine. Vet. Clin. N. Am. Exot. Anim. Pract., v.16, p.211-225, 2013.

MENDONÇA Jr, C.X.; MARTINS, A.P.; MORI, A.V. et al. Efeito da adição de óleo de peixe à dietas sobre o desempenho e níveis de lipídios plasmáticos e de colesterol no ovo de galinhas poedeiras. Braz. J. Vet. Res. Anim. Sci., v.47, p.79-83, 2000.

MILLER, D.; ROBISCH, P. Comparative effect of herring, menhaden, and safflower oils on broiler tissues fatty acid composition and flavor. Poult. Sci., v.48, p.2146-2157, 1969.

NAIDOO, V.; DIEKMANN, M.; WOLTERS, K. et al. Establishment of selected baseline blood chemistry and hematologic parameters in captive and wild-caught African white-backed vultures (Gyps africanus). J. Wildl. Dis., v.44, p.649-654, 2008.
NEIJAT, M.; OJEKUDO, O; HOUSE, J.D. Effect of flaxseed oil and microalgae DHA on the production performance, fatty acids and total lipids of egg yolk and plasma in laying hens. Prostaglandins Leukot. Essent. Fatty Acids, v.115, p.77-88, 2016.

OLIVEIRA, J.F. Diferentes relações ômega6/ômega-3 na dieta degalinhas poedeiras. 2018. 60f. Dissertação (Mestrado em Ciência e Tecnologia Animal) - Faculdade de Ciências Agrárias e Tecnológicas, Universidade Estadual Paulista "Júlio de Mesquita Filho", Dracena, SP.

ORTIZO, K.A.; CUYACOT, A.R.; MAHILUM, J.J.M. et al. Plasma biochemistry levels and hematological parameters in Mallard ducks (Anas platyrhynchos Linn.) from selected semi-free range duck farms in Misamis Occidental and Zamboanga Del Sur, Philippines. Amin. Biol. Anim. Husbandry Int. J. Bioflux Soc., v.6, p.5062, 2014.

PINCHASOV, Y.; NIR, I. Effect of dietary polyunsaturated fatty acid concentration on performance, fat deposition and carcass fatty acid composition in broiler chickens. Poult. Sci., v.71, p.1504-1512, 1992.

PUCCI, L.E.A.; RODRIGUES, P.B.; FREITAS, R.T.F. et al. Níveis de óleo e adição de complexo enzimático na ração de frangos de corte. Rev. Bras. Zootec., v.32, p.909-917, 2003.

RAJMAN, M.; JURÁNI, M.; LAMOSOVA, D. et al. The effects of feed restriction on plasma biochemistry in growing meat type chickens (Gallusgallus). Comp. Biochem. Physiol. A Mol. Integr. Physiol., v.145, p.363-371, 2006.

REZENDE, M.S. Perfil bioquímico sanguíneo de linhagem pesada de frango de corte. 2017. 63f. Tese (Doutorado em Ciências Veterinárias) Faculdade de Medicina Veterinária, Universidade Federal de Uberlândia. Uberlândia, MG.

ROSTAGNO, H.S.; ALBINO, L.F.T.; HANNAS, M.I. et al. Tabelas brasileiras para aves e suínos: composição de alimentos e exigências nutricionais. Viçosa: UFV, 2017. 488p.

SCHMIDT, E.M.S.; PAULILLO, A.C.; SANTIN, E. et al. Hematological and serum chemistry values for the ring-necked pheasant (Phasianus colchicus): variation with sex and age. Int. J. Poult. Sci., v.6, p.137-139, 2007. 
SILVA, J.E.S.; MOURA, A.M.A.; NOGUEIRA, R.A. Efeito dos ácidosgraxos essenciais sobre lipidemia e vascularização da membrana vitelina de codornas japonesas. Arq. Bras. Med. Vet. Zootec., v.64, p.1603-1612, 2012.

SILVA, A.F.; CRUZ, F.G.G.; RUFINO, J.P.F. et al. Fish by-product meal in diets for commercial laying hens. Acta Sci. Anim. Sci., v.39, p.273-279, 2017.

SPOSITO, A.C.; CARAMELLI, B.; FONSECA, F.A.H. et al. 4 Diretriz Brasileira Sobre Dislipidemias e Prevenção da Aterosclerose Departamento de Aterosclerose da Sociedade Brasileira de Cardiologia. Sociedade Brasileira de Cardiologia. Arq. Bras. Cardiol., v.88, Supl.1, 2007.
SWENSON, M.; O'REECE, W. Dukes. Fisiologia dos animais domésticos. Cornell: Cornell University Press, 1996.

THRALL M.A.; BAKER, D.C.; CAMPBELL, T.W. et al. Veterinary hematology and clinical chemistry. Lippincott: Williams \& Wilkins, 2004. $618 \mathrm{p}$. 